\title{
First record of Chaunus achavali (Anura, Bufonidae) from Rio Grande do Sul, Brazil, with a key for the identification of the species in the Chaunus marinus group
}

\author{
Axel Kwet ${ }^{1}$, Marcos Di-Bernardo ${ }^{2,4}$ \& Raúl Maneyro ${ }^{2,3}$
}

1. Staatliches Museum für Naturkunde, Zoologie, Rosenstein 1, D-70191 Stuttgart, Germany. (kwet.smns@naturkundemuseum-bw.de)

2. Laboratório de Herpetologia, Museu de Ciências e Tecnologia \& Faculdade de Biociências da Pontifícia Universidade Católica de Rio Grande do Sul, Av. Ipiranga 6681, 90619-900 Porto Alegre, RS, Brazil.

3. Sección Zoología Vertebrados, Facultad de Ciencias, Universidad de la República, Iguá 4225, 11400 Montevideo, Uruguay. (rmaneyro@fcien.edu.uy)

4. Deceased.

\begin{abstract}
The bufonid toad Chaunus achavali, a recently described species known only from Uruguay, is recorded for Brazil. This species is morphologically similar to $C$. ictericus and C. arenarum, and several individuals were labeled in Brazilian scientific collections under these taxa. A lectotype of $C$. arenarum is designated. Additional field notes on $C$. achavali and a key for the identification of the species in the Chaunus marinus group are presented.
\end{abstract}

KEYWORDS. Chaunus marinus species group, Chaunus achavali, new record, southern Brazil.

RESUMO. Chaunus achavali, uma espécie de bufonídeo recentemente descrita e conhecida apenas para o Uruguai, é registrada para o Brasil. Esta espécie é morfologicamente similar a $C$. ictericus e $C$. arenarum, sendo que vários espécimes foram rotulados com esses nomes em coleções científicas brasileiras. É designado um lectótipo para $C$. arenarum. São apresentadas notas de campo sobre $C$. achavali e uma chave para identificação das espécies do grupo C. marinus.

PALAVRAS-CHAVE. Grupo Chaunus marinus, Chaunus achavali, novo registro, sul do Brasil.

Within the genus Chaunus Wagler, 1828 (Bufonidae), more than 40 species arranged in eight phenetic groups are known from the Neotropical region (Duellman \& Schulte, 1992; Frost, 2004; Frost et al., 2006). Members of the Chaunus marinus species group are distributed throughout most of Central and South America (Cei, 1972; Martin, 1972; Duellman \& Schulte, 1992), and Chaunus marinus (Linnaeus, 1758) was also introduced in Oceania, where it became an invasive species (Duellman \& Trueb, 1994). Recently, two new species were described in this group: Chaunus jimi (Stevaux, 2002), from the Brazilian State of Bahia, which is closely related to C. schneideri (Werner, 1894) (also known as C. paracnemis (Lutz, 1925), which was considered a junior synonym by Gallardo, 1962; see discussion in Frost, 2004), and Chaunus achavali (Maneyro, Arrieta \& Sá, 2004), from Uruguay, which is related to $C$. arenarum (Hensel, 1867) and C. rubescens (Lutz, 1925). Bufo rufus Garman, 1877 was considered a primary homonym of Bufo rufus Schneider, 1799 [(= Bufo terrestris (Bonnaterre, 1789)] by LAVILLA (1992), and will be treated here as a synonym of Chaunus rubescens (see Frost, 2004).

Hence, the Chaunus marinus group currently contains eight species: $C$. achavali (Maneyro et al., 2004), C. arenarum (Hensel, 1867), C. ictericus (Spix, 1824), C.jimi (Stevaux, 2002), C. marinus (Linnaeus, 1758), C. poeppigii (Tschudi, 1845), C. rubescens (Lutz, 1925), and C. schneideri (Werner, 1894). Chaunus arenarum mendocinus (Philippi, 1869), is the only subspecies in the Chaunus marinus group which is actually recognized as valid (besides the nominal taxon) (LAVILLA \& CEI, 2001). Two other subspecies, C. arenarum platensis (Jiménez de la Espada, 1875) and C. a. chaguar (Gallardo, 1965), were synonymized by LAURENT (1969), although CEI (1980) implied that they might be valid. Another controversial taxon is Bufo missionum Berg, 1896, which was treated as a junior synonym of Bufo rufus (here Chaunus rubescens) by GALLARDO (1961) and is now considered a synonym of Chaunus ictericus (FAIVOVICH \& CARRIZO, 1997).

During fieldwork in the Municipality of Candiota, south of state of Rio Grande do Sul, Brazil (DI-BERNARDO \& Kwet, 2002; Di-Bernardo et al., 2004), we collected several specimens of an unidentified species of Bufo. These specimens, superficially similar to $C$. arenarum and $C$. ictericus, were preliminary determined as Bufo sp. (aff. arenarum) in Kwet (2001), and as Bufo sp. in DIBERNARDO et al. (2004). A single individual belonging to the same taxon was later collected in the Municipality of Quinze de Novembro, and another specimen was photographed in the Municipality of Agudo, both localities situated in central Rio Grande do Sul. Additional specimens labeled under the names $C$. arenarum or $C$. ictericus, were identified in the collections of Universidade Federal do Rio Grande do Sul, Universidade Federal de Santa Maria, and Museu de Ciências Naturais da Fundação Zoobotânica do Rio Grande do Sul. To confirm the species identity, we re-examined all individuals and compared them with the type material of Chaunus achavali and $C$. arenarum, and with additional specimens of $C$. arenarum and C. ictericus. Our comparison revealed that the unidentified specimens collected by us belong 
to Chaunus achavali. The aim of this publication is: (1) to report the first record of Chaunus achavali for Brazil; (2) to present life history notes of this poorly known species; (3) to remark on the type specimens of Chaunus arenarum; and (4) to provide an artificial key for the identification of adult toads in the Chaunus marinus group, based on external morphology.

\section{MATERIAL AND METHODS}

Fieldwork took place in the Municipality of Candiota $\left(31^{\circ} 32^{\prime} \mathrm{S}, 5^{\circ} 45^{\prime} \mathrm{W}\right.$; 100-300 $\mathrm{m}$ a.s.l.), from December 1999 to March 2002. This locality lies about $235 \mathrm{~km}$ airline from the type locality of Chaunus achavali. Additional field observations were made on 14th February 2002 in the Municipality of Quinze de Novembro, about $315 \mathrm{~km}$ airline from Candiota, and 536 $\mathrm{km}$ airline from the type locality, and in the Municipality of Agudo, $218 \mathrm{~km}$ airline from Candiota, and $442 \mathrm{~km}$ airline from the type locality. Distances between mentioned localities were calculated with the version 12.3 of the software GPS Trackmaker, developed by Odilon Ferreira Junior (available free at http://www.gpstm.com.br).

Institutional acronyms are as follows: CEPB, Coleção Herpetologica, Universidade Católica de Goiás, Brazil; CHUNB, Coleção Herpetologica, Universidade de Brasília, Brazil; DZUFRGS, Coleção Herpetologica, Departamento de Zooogia da Universidade Federal de Rio Grande do Sul, Brazil; MCN, Museu de Ciências
Naturais, Fundação Zoobotânica do Rio Grande do Sul, Brazil; MCP, Museu de Ciências e Tecnologia, Pontifícia Universidade Católica de Rio Grande do Sul, Brazil; MNHN, Museo Nacional de Historia Natural de Montevideo, Uruguay; MZUSP, Museu de Zoologia, Universidade de São Paulo, Brazil; ZMB, Museum für Naturkunde, formerly Zoologisches Museum Berlin, Germany; ZUFSM, Coleção Herpetologica da Universidade Federal de Santa Maria, Brazil; ZVCB, Colección de Anfibios, Zoología Vertebrados, Facultad de Ciencias, Universidad de la República, Uruguay.

We collected a total of 13 specimens in Candiota (MCP 3936, 3937, 3938, 3939, 3940, 3941, 3973, 4095, 4374, 4375, 4466, 4467, 4468), and one (MCP 5687) in Quinze de Novembro. Additional material from Caçapava do Sul, Candiota (Vila Residencial), Ivorá (Barreiro), Pelotas (Três Igrejinhas), Pinhal Grande, and São Jerônimo was found in the DZUFRGS, MCN, MCP, and ZUFSM collections. All localities currently known for C. achavali are mapped in Fig. 1.

In order to designate a lectotype for Chaunus arenarum, we examined the type material present in the Museum für Naturkunde, Berlin. Measurements of these specimens were taken to the nearest $0.1 \mathrm{~mm}$ using digital calipers. Additional material, including type specimens of Chaunus achavali, $C$. arenarum and C. jimi, and specimens of $C$. ictericus, $C$. marinus, $C$. rubescens, and C. schneideri, were compared in order to construct an identification key to the species in the $C$. marinus group.

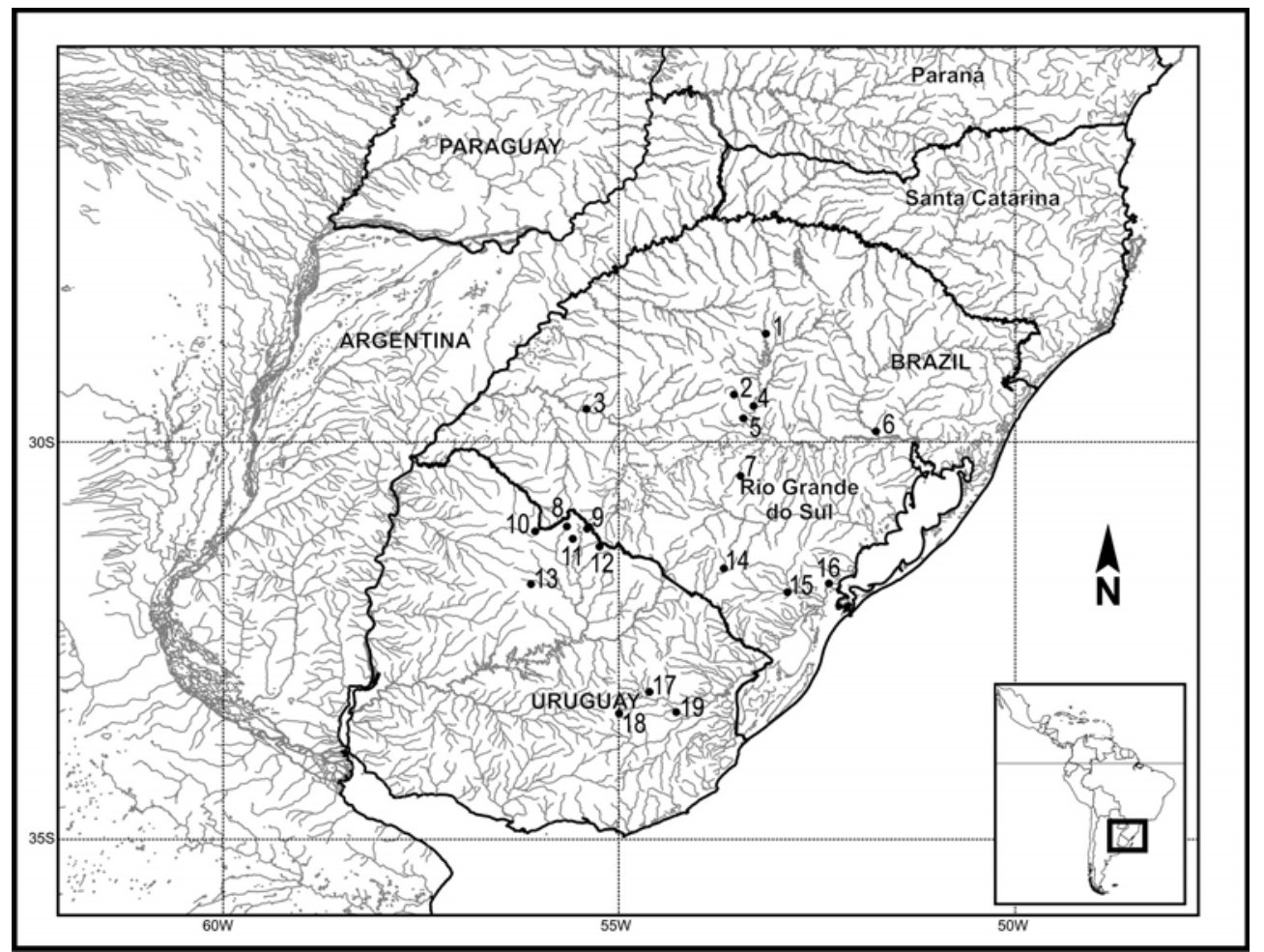

Fig. 1. Known distribution of Chaunus achavali: 1, Quinze de Novembro; 2, Ivorá; 3, Manoel Viana; 4, Agudo; 5, Pinhal Grande; 6, São Jerônimo; 7, Caçapava do Sul; 8, Sierra de la Aurora; 9, Trinidad Farm; 10, Arroyo de la Invernada; 11, Velázquez Farm; 12, Capón Alto Farm; 13, Gruta de los Cuervos; 14, Candiota; 15, Pedro Osorio; 16, Pelotas; 17, Estancia "Doña Alba"; 18, Outskirts of Pueblo Valentines (type locality); 19, Arroyo Yerbal Grande. 
Specimens examined:

Chaunus achavali-BRAZIL, Rio Grande do Sul: Barreiro, Ivorá (ZUFSM 2784, 2785, 2800); Caçapava do Sul (MCN 9133, 9134, 9135); Caçapava do Sul, Passo do Moinho (ZUFSM 3364, 33655); Candiota (MCP 3936, 3937, 3938, 3939, 3940, 3941, 3973, 4095, 4374, 4375, 4466, 4467, 4468); Candiota, Vila Residencial (DZUFRGS 1007, 1008); Pelotas, Três Igrejinhas (ZUFSM 3841); Pinhal Grande (ZUFSM 2313); Quinze de Novembro (MCP 5687); São Jerônimo (MCP 8326). URUGUAY, Artigas: Arroyo de la Invernada (ZVCB 77, 84). Rivera: Sierra de la Aurora (ZVCB 3331). Tacuarembó: Gruta de los Cuervos (ZVCB 271A; 271B). Treinta y Tres: Afueras de Pueblo Valentines (ZVCB 3779 - Holotype); Arroyo Yerbal Grande (ZVCB 3815); Estancia “DoñaAlba(ZVCB 3801, 4031, 4727).

Chaunus arenarum - ARGENTINA, La Pampa: vicinity of Ciudad de Santa Rosa, Laguna Guanaco (ZVCB 519/1; 519/3; 519/4; 519/5; 519/6; 519/8; 519/9). BRAZIL, Rio Grande do Sul: Estação Ecológica do Taim (MZUSP 57530, 57531, 57532, 57533); Rio Grande (DZUFRGS 20, 21, 22, 23, 24, 25, 215, 216, 217, 218; MCN 5230; ZMB 6779 - Lectotype, 57370, 57371 Paralectotypes); Rio Grande, Praia do Cassino (MCN 10288, 10289, 10290, 10291, 10292, 10293, 10294, 10295, 10296, 10297, 10298, 10299); Tramandaí (MZUSP 27344, 27345, 27346). URUGUAY, Canelones: Boca del Arroyo Carrasco (ZVCB 3316, 3317); Costa Azul (ZVCB 3276); Parque del Plata (ZVCB 1107); Maldonado: Zanja de los Alemanes (ZVCB 311). Montevideo: Carrasco (ZVCB 511/ 1; 511/2; 511/3); Isla de Flores (ZVCB 343); Montevideo, Mart y Berro, Facultad de Humanidades y Ciencias (ZVCB 1402); Puerto del Buceo (ZVCB 278). Paysandú: Puente Internacional (ZVCB 2758). Rocha: Aguas Dulces (ZVCB 143); Cabo Santa María (ZVCB 827); Cabo Polonio (ZVCB 1746, 1747, 1748, 1749). Salto: Ciudad de Salto, Club de Remeros (ZVCB 3459).

Chaunus ictericus -BRAZIL, Rio Grande do Sul: Campo Bom (MNHN2211, 4220); Caçapava do Sul, Guaritas (ZUFSM 3438); São Francisco de Paula, Potreiro Novo, PróMata PUCRS (MCP 7924). São Paulo: Jundiaí (ZVCB 3595).

Chaunus marinus-BRAZIL, Pará: Alter do Chão (MZUSP 29005, 29006, 29007, 29008). PERU, Loreto: Alto Cuaranjá (MZUSP 10320, 10322, 10323, 10325).

Chaunus rubescens-BRAZIL, Distrito Federal: Brasília (CHUNB 12950, 14959, 29387, 33793). Goiás: Caldas Novas, Usina Hidroelétrica Corumbá (CEPB 675, 3400, 5162, 6190, 6217, 6709, 7619, 8216, 10801, 14687, 15710, 17346). Minas Gerais: Paracatu (CHUNB 26459, 26460, 26464, 26465, 26466, 26467).

Chaunus schneideri-BRAZIL, Rio Grande do Sul: Barra do Quaraí (MCN 12171); Manoel Viana, rio Ibicuí (ZUFSM 2424); Rosário do Sul (MCP 5717); Uruguaiana (MCP 1964, 3910; MCN 6425, 6431). URUGUAY, Artigas: Arrocera Conti (ZVCB 1666); Arrocera Conti $25 \mathrm{~km} \mathrm{~W}$ of Colonia Palma (ZVCB 3145); Bella Unión (ZVCB 88A, 88B, 88C, 88D, 88E, 406); San Gregorio (ZVCB 1062). Salto: lagoon in Ciudad de Salto
(ZVCB 1568, 1569, 1570); El Espinillar (ZVCB 3221, 3222); Parador Quiroga, río Uruguay (ZVCB 1477); río Arapey Grande $4 \mathrm{~km}$ of las Termas (ZVCB 1220).

\section{RESULTS}

Morphology. For our comparisons, we studied the type material of Chaunus arenarum, which has never been examined since the original description of this species. In the ZMB collection, we found three syntypes, out of seven specimens mentioned by Hensel (1867). These three specimens are in a rather good condition and were originally catalogued under ZMB 6779. Now they are housed under three separate numbers: ZMB 6779, ZMB 57370 and ZMB 57371 (Figs. 2-7). To prevent taxonomic problems in the future, we herein designate ZMB 6779, the largest specimen, as the lectotype of $C$. arenarum, and ZMB 57370 and 57371 as paralectotypes (see Table I for measurements of these three type specimens).

Our morphological comparison between $C$. arenarum, including living specimens, and the recently collected material from Candiota and Quinze de Novembro revealed that they belong to distinct species (Figs. 4, 5). The differences, e.g., in shape of parotoid glands (inner margin concave in C. achavali and sinuous in $C$. arenarum), development of cranial crests (sharper in $C$. achavali), development of toe membranes (bigger in C. achavali), and general dorsal coloration (light cream, sometimes yellowish-gray in $C$. arenarum versus dark brown, ferruginous in $C$. achavali) are significant and sometimes already visible in juveniles (Figs. 6, 7). A comparison with the other two species of the $C$. marinus group known from Rio Grande do Sul, C. schneideri (Fig. 8) and C. ictericus (Fig. 9), also demonstrated clear morphological differences, e.g., presence of paracnemic (tibial) glands in C. schneideri (absent in C. achavali), well developed, subtriangular parotoid glands in $C$. schneideri and $C$. ictericus (small and cylindrical in $C$. achavali), and less developed foot web in C. schneideri and $C$. ictericus (well developed in $C$. achavali). On the other hand, when comparing our specimens with $C$. achavali we did not find differences, meaning they are

Table I. Measurements (in $\mathrm{mm}$ ) of former syntypes of Chaunus arenarum (three specimens). ZMB 6779 is designated as lectotype; ZMB 57370 and ZMB 57371 are paralectotypes.

\begin{tabular}{lccc}
\hline & ZMB 6779 & ZMB 57370 & ZMB 57371 \\
\hline Snout-vent length & 7.24 & 6.87 & 5.70 \\
Head length & 2.33 & 2.13 & 1.93 \\
Head width & 2.80 & 2.52 & 2.09 \\
Eye diameter & 0.71 & 0.72 & 0.59 \\
Tympanum diameter & 0.50 & 0.46 & 0.43 \\
Eye-nostril distance & 0.44 & 0.43 & 0.33 \\
Interorbital distance & 0.60 & 0.56 & 0.39 \\
Internarial distance & 0.51 & 0.44 & 0.36 \\
Femur length & 2.73 & 2.50 & 2.17 \\
Foot length & 2.68 & 2.53 & 2.24 \\
Parotoid length & 1.76 & 1.70 & 1.36 \\
\hline
\end{tabular}


conspecific. At Agudo and Quinze de Novembro, $C$. achavali and $C$. ictericus were found in sympatry (Fig. 10), and at Agudo a third species of the group, $C$. schneideri, was also recorded.

Key for the identification of the species in the Chaunus marinus group

1. Presence of tibial glands .2

Absence of tibial glands ........................................... 3

2. With distinct glands on forearms and on both sides of the cloaca (following Stevaux, 2002) .......... C. jimi

Without these glands .......................... . schneideri

3. Parotoid glands elongated, cylindrical, more than twice as long as broad, never triangular or subtriangular

Parotoid glands not elongated, bulky, with longitudina diameter less than twice transversal diameter ..... 6

4. Snout acuminate in dorsal view; cephalic crest over the orbit not prominent, lower than eyelid in fixed specimens C. rubescens

Snout less acuminate, almost rounded in dorsal view; cephalic crest over the orbit prominent or not in fixed specimens....
5. Webbing between toes well developed; inner margin of parotoid glands concave; cephalic crest over the orbit prominent, higher than eyelid; dorsal coloration dark brown, ferruginous (at least in cephalic crests and glands), ventral coloration whitish, without dark markings ......... C. achavali

Webbing between toes less developed; inner margin of parotoid gland sinuous; cephalic crest over the orbit not prominent, lower than eyelid in fixed specimens; dorsal coloration light cream, sometimes yellowish-gray, never reddish or ferruginous, ventral coloration whitish speckled with gray markings .

C. arenarum

6. Outline (circumference) of the parotoid gland smaller than the outline of the lateral surface of the head

Outline of the parotoid gland greater than the outline of the lateral surface of the head ......... C. marinus

7. Ratio of the diameter of tympanum to the diameter of eye usually smaller than 0.4

C. poeppigii

Ratio of the diameter of tympanum to the diameter of eye usually greater than 0.4 . C. ictericus
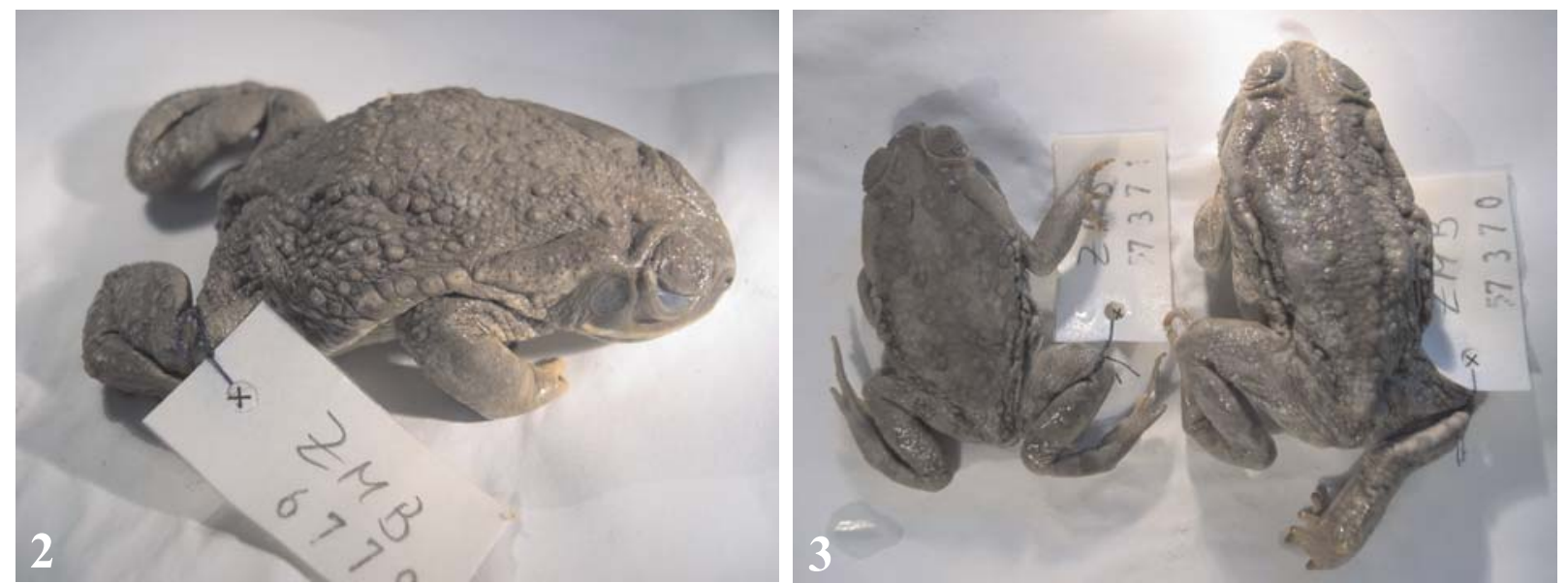

Figs. 2-3. Chaunus arenarum. 2, designated lectotype in dorsolateral view (ZMB 6779); 3, dorsal view of paralectotypes (ZMB 57370, 57371).
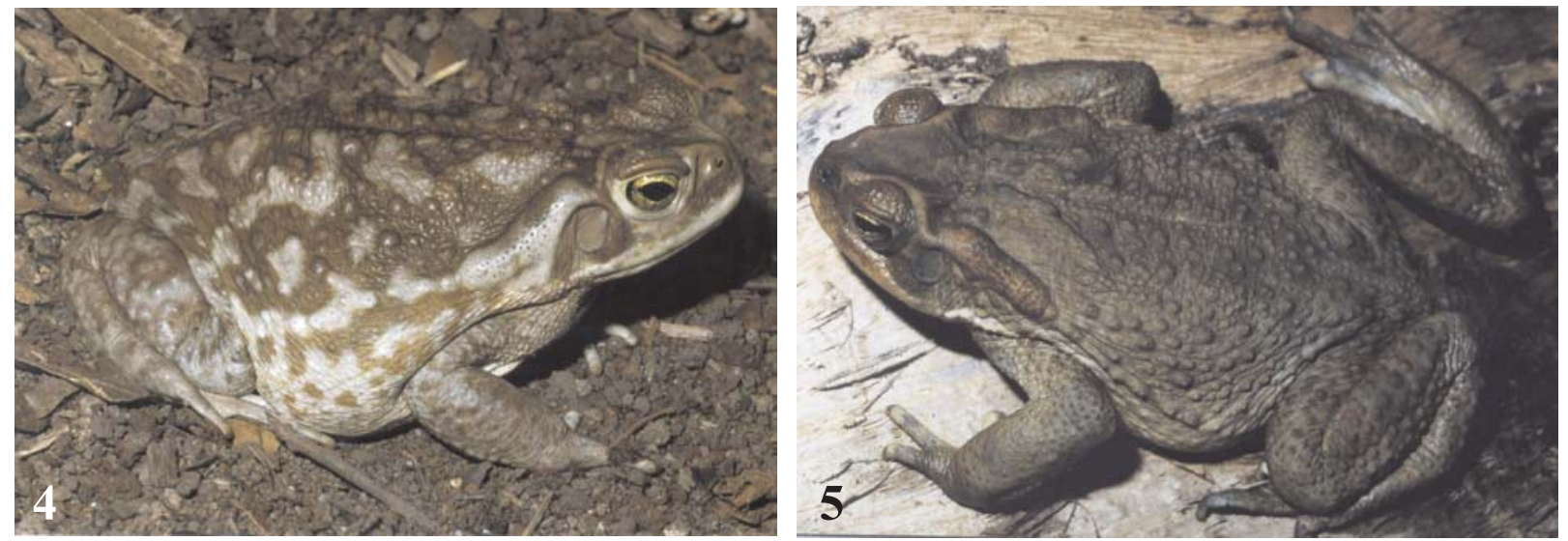

Figs. 4-5. Adults. 4, Chaunus arenarum from Capão da Canoa, Rio Grande do Sul; 5, Chaunus achavali from Candiota, Rio Grande do Sul. 
Field notes. During our fieldwork in Candiota, Chaunus achavali was occasionally observed in or near small forest streams, in elevations around $160 \mathrm{~m}$ a.s.l. The first seven specimens (MCP 3936, 3937, 3938, 3939,
3940, 3941, 3973, all adults except MCP 3941) were collected on 21th December 1999, in activity at night, most of them out of water, along the margins of a small stream (G. F. Pontes, pers. com.). Most adult individuals
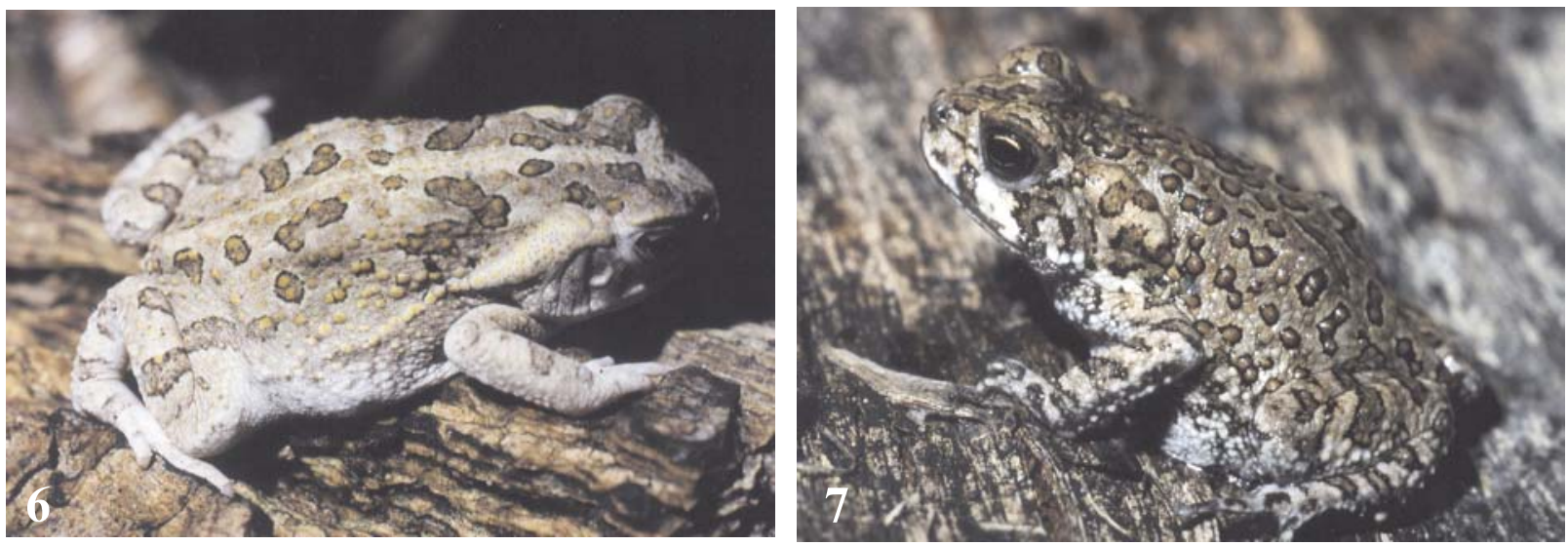

Figs. 6-7. Juveniles. 6, Chaunus arenarum from Rio Grande, Rio Grande do Sul; 7, Chaunus achavali (MCP 3941) from Candiota, Rio Grande do Sul.
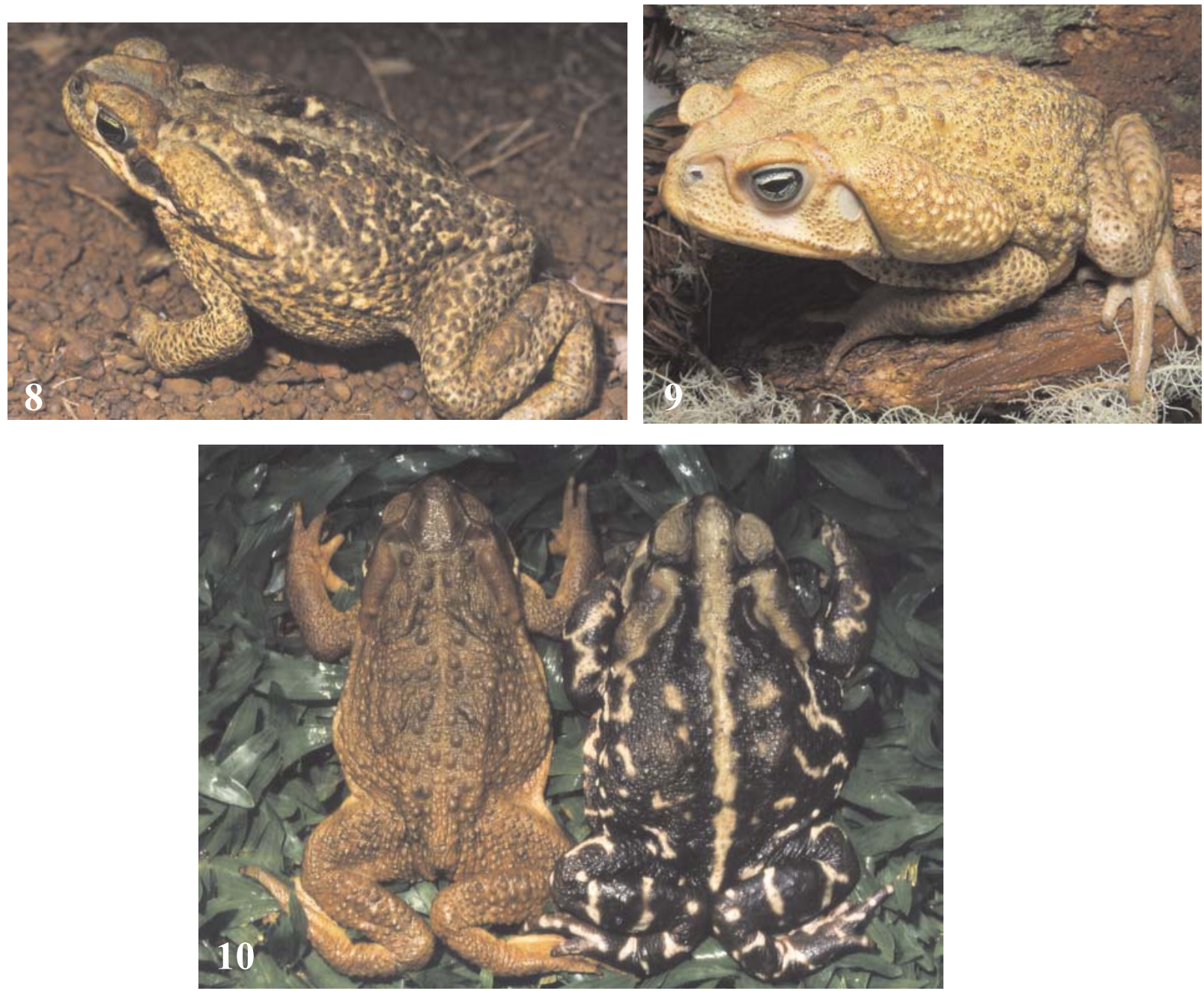

Figs. 8-10. Adults. 8, Chaunus schneideri from São Borja, Rio Grande do Sul. Note the presence of tibial glands; 9, Adult Chaunus ictericus (male) from São Francisco de Paula, Rio Grande do Sul; 10, Comparison between Chaunus achavali (left) and C. ictericus (right, female), found in sympatry in the municipality of Quinze de Novembro, Rio Grande do Sul. Note differences in development of cranial crests and feature of the parotoid glands. 


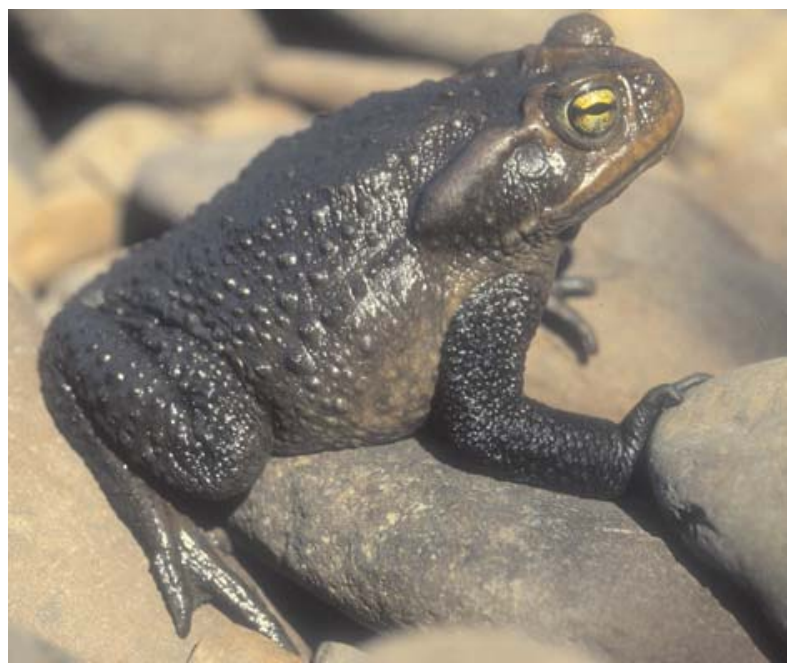

Fig. 11. Specimen of Chaunus achavali photographed in its place of finding (margin of the Jacuí river) in Agudo, Rio Grande do Sul (not collected). Note the well-developed webbing between toes. Photo: M. Borges-Martins.

were found perched on tree-trunks, about $20-50 \mathrm{~cm}$ above the water surface, and some specimens under stones. One male was sitting in the water. Despite the concomitant presence of adult males and females at the same site, we did not hear advertisement calls, and did not find eggs or tadpoles. The MCP 3941 is figured here (Fig. 7) to illustrate the different dorsal coloration of living juveniles. Whereas adults of $C$. achavali (Fig. 5) are uniformly brownish or reddish, ferruginous on dorsum, juveniles possess a conspicuous pattern of orange and creamcolored blotches, which are irregularly arranged in several longitudinal lines. Other two individuals (MCP 4095 and 4374), with well developed nuptial pads, were collected in October 2000 and January 2001, in water collections with $\mathrm{pH}=9.00$ and $\mathrm{pH}=6.82$, respectively. Three juveniles (MCP 4466, 4467 and 4468) were collected in 12th January 2001 , inactive under stones, between $17 \mathrm{~h}$ and $18 \mathrm{~h} 30 \mathrm{~min}$.

The specimen from Quinze de Novembro (MCP 5687) was found on 14th February 2002 at day, sitting in the water at the margin of a small stream, near Santa Clara do Ingaí. The specimen photographed in Agudo (Fig. 11, not collected) was found in 6th January 2001 at morning, walking over rounded, river-rolled stones, at the left margin of the Jacuí river.

\section{DISCUSSION}

In his description of Chaunus arenarum, HeNSEL (1867) mentioned seven specimens, which he had collected "bei der Stadt Rio-Grande do Sul" (= near the city of Rio Grande do Sul [Brazil]). This type locality was later specified as "Rio Grande, Rio Grande do Sul Brazil" by BoKERMANN (1966). Frost (2004) noted that the deposit location of type specimens was not designated but that the syntypes are probably in the ZMB collection, Berlin. Actually, we localized a jar with three type specimens in the Berlin collection, herein designating ZMB 6779 as the lectotype of Chaunus arenarum (Hensel, 1867). The remaining four type specimens could not be located.
Up to date, Chaunus achavali was only known from six localities in the Departamentos of Treinta y Tres, Tacuarembó, Artigas, and Rivera, in northeastern Uruguay (MANEYRo et al., 2004). Our new records from the neighboring Brazilian State of Rio Grande do Sul extend the geographic range of this species about 382 $\mathrm{km}$ NE from previous cited localities. The record from Quinze de Novembro represents the northernmost and also the highest (374 $\mathrm{m}$ a.s.l.) locality known to date for this species. Due to its small distribution range, MANEYRO \& LANGONE (2001) classified C. achavali (as Bufo sp.) as potentially threatened in Uruguay. Data are still insufficient to assess the distribution range and threat category of this species in Rio Grande do Sul, but $C$. achavali may have a wider distribution than presently acknowledged, being sometimes mistaken for $C$. arenarum or $C$. ictericus. The key to adult toads in the $B$. marinus group presented here should allow a correct identification of this species.

Little is known about the life history of $C$. achavali. MANEYRo et al. (2004) reported small streams in hill regions as the most occupied habitat of this species. This agrees with our observations in Rio Grande do Sul. Whereas most toads of the genus Chaunus are terrestrial or fossorial, and breed in lentic aquatic environments (mainly species in the C. marinus group, pers. obs.), we observed adults of $C$. achavali perching on fallen tree trunks and branches near (just above) or inside streams and rivers. The well-developed webbing between toes (see Fig. 11) appears to be an adaptation for better dislocation in lotic waters. The dorsal skin of males with nuptial pads exhibited cornified skin tubercles. These tubercles are interpreted as a secondary sexual characteristic of adult males, as described for other bufonid species (Duellman \& Trueb, 1994). This characteristic was very conspicuous in individuals collected during the end of Spring and the first Summer months, enforcing the idea that $C$. achavali has a seasonal reproductive activity, with its peak during the warm season. Although we could not directly observe calling or breeding activity, we found a gravid female (MCP 4375) in January. However, advertisement calls and tadpoles of this species are still unknown. We have worked for a long time in Candiota (more than two years), searching for anurans mainly in ponds and other lentic bodies of water. In such places, we found calling males, eggs, tadpoles or juveniles of all the 22 recorded species (DIBERNARDO et al., 2004), with the exception of C. achavali. We think it is plausible to assume here that $C$. achavali do not use lentic collections of water, living and breeding in streams and rivers.

Acknowledgements. We are indebt to the curators and collaborators of the visited collections: Laura Verrastro (DZUFRGS), Márcio Borges-Martins (MCN), Mariana G. Zatz, Guarino R. Colli and Reuber Brandão (CHUNB), Miguel T. U. Rodrigues and Paulo E. Vanzolini (MZUSP), Nelson J. da Silva Jr. (CEPB), Sonia T.Z. Cechin (ZUFSM), and Rainer Günther (ZMB). Reuber Brandão and Natan Maciel kindly took measurements from the types of Chaunus jimi. Glaucia Pontes provided some field notes. We acknowledge Dr. M. B. Martins (MCN) for valuable help in the handling of the manuscript as for give us the basis of Figure 1. The "Candiota Project", which gave the opportunity for collecting many of the Chaunus achavali specimens from 
Brazil, was financed by CNPq/PADCT/CIAMB (Process CIAMB \# 01/97-03/02). MD is partially financed by the Conselho Nacional de Desenvolvimento Científico e Tecnológico (Process CNPq \# 307.992/2004-7), and RM has a doctoral fellowship from Coordenação de Aperfeiçoamento de Pessoal de Nível Superior (CAPES).

\section{REFERENCES}

Bokermann, W. C. A. 1966. Lista anotada das localidades tipo de anfíbios brasileiros. São Paulo, Serviço de Documentação RUSP. $183 \mathrm{p}$.

CEI, J. M. 1972. Bufo of South America. In: Blair, W. F. ed Evolution in the genus Bufo. Austin, University of Texas. p.82-92.

. 1980. Amphibians of Argentina. Monitore zoologico italiano (Nuova Serie) 2:1-609.

Di-Bernardo, M. \& Kwet, A. 2002. Efeitos da contaminação de águas superficiais associadas a atividades de extração e processamento de carvão sobre anfíbios. In: TeixeIrA, E. C. \& PIRES, M. J. R. coords. Meio ambiente e carvão. Impactos da exploração e utilização. Porto Alegre, PADCT / GTM / FINEP / CAPES / PUCRS / UFSC / FEPAM. p.413-422 .

Di-Bernardo, M.; Oliveira, R. B.; Pontes, G. M. F.; Melchiors, J.; Solé, M. \& Kwet, A. 2004. Anfíbios anuros da região de extração e processamento de carvão de Candiota, RS, Brasil. In: Teixeira, E. C. \& Pires, M. J. R. orgs. Estudos ambientais em Candiota: carvão e seus impactos. Porto Alegre, FEPAM. p.163-175.

Duellman, W. E. \& Schulte, R. 1992. Description of a new species of Bufo from northern Peru with comments on phenetic groups of South American toads (Anura: Bufonidae). Copeia 1992:162-172.

Duellman, W. E. \& Trueb, L. 1994. Biology of amphibians. Baltimore, John Hopkins University. 670p.

Faivovich, J. \& Carrizo, G. R. 1997. La identidad de Bufo missionum Berg, 1896 (Anura, Bufonidae). Cuadernos de Herpetología 11(1-2):81-82.

Frost, D. R. 2004. Amphibian species of the world: an online reference. Version 3.0 (22 August, 2004). American Museum of Natural History, New York, USA. Available at: <http://research.amnh.org/herpetology/amphibia/index.html>. Access on: 30.March.2005.

Frost, D.; Grant, T.; Faivovich, J.; Bain, R.; HaAs, A.; Haddad, C. De Sá, R.; Channing, A.; Wilkinson, M.; Donnellan, S.; RaXworthy, C.; Campbell, J.; Blotto, B.; Moler, P.; Drewes, R. C.; Nussbaum, R.; Lynch, J.; GreEn, D. \& Wheeler, W. 2006. The amphibian tree of life. Bulletin of the American Museum of Natural History 297: 1-370.

Gallardo, J. M. 1961. Anfibios anuros de Misiones con la descripción de una nueva especie de Crossodactylus. Neotropica 7(22):33-38.

. 1962. A propósito de Bufo variegatus (Günther), sapo del Bosque Húmedo Antartándico, y las otras especies de Bufo neotropicales. Physis 23(64):93-102.

Hensel, R. 1867. Beiträge zur Kenntniss der Wirbelthiere Südbrasiliens. Wiegmanns Archiv für Naturgeschichte 33(1/2):120-162.

Kwet, A. 2001. Frösche im brasilianischen Araukarienwald - Anurengemeinschaft des Araukarienwaldes von Rio Grande do Sul: Diversität, Reproduktion und Ressourcenaufteilung. Münster, Natur und Tier-Verlag, 192p.

LAURENT, R. 1969. Las supuestas razas de Bufo arenarum y el concepto de subespecie críptica. Acta Zoológica Lilloana 25(6):67-80.

LaviLla, E. O. 1992. Tipos portadores de nombre y localidades tipo de Anfibios de Argentina. Acta Zoológica Lilloana 42(1):61-100.

Lavilla, E. O. \& Cei, J. M. 2001. Amphibians of Argentina. A second update, 1987-2000. Torino, Museo Regionale di Scienze Naturali di Torino. 178p (Monografie 28).

Maneyro, R. \& Langone, J. A. 2001. Categorización de los anfibios del Uruguay. Cuadernos de Herpetología 15:107-118.

Maneyro, R.; Arrieta, D. \& de SÁ, R. 2004. A new toad (Anura: Bufonidae) from Uruguay. Journal of Herpetology 38 (2): $161-165$.

Martin, R. F. 1972. Evidence from osteology. In: Blair, W. F. ed. Evolution in the genus Bufo. Austin, University of Texas. 37-70p.

Stevaux, N. 2002. A new species of Bufo Laurenti (Anura, Bufonidae) from northeastern Brazil. Revista Brasileira de Zoologia 19(Supl.):235-242. 